\title{
PENGEMBANGAN BUSINESS INTELLIGENCE BAGI PERKEMBANGAN BISNIS PERUSAHAAN
}

\author{
Eka Miranda \\ Jurusan Sistem Informasi, Fakultas Ilmu Komputer, Universitas Bina Nusantara, \\ Jln. K.H. Syahdan No.9, Palmerah, Jakarta Barat 11480 \\ ekamiranda@yahoo.com
}

\begin{abstract}
This article discusses the Business Intelligence and its role to improve the company's competitive advantage through the utilization of various data, information and knowledge held by the company as a raw material in the decision making process. This article also explains the elements of Business Intelligence applications, Business Intelligence Environment, integrating BI into the enterprise and the challenges faced by organizations in giving effect to Business Intelligence.

Keywords: Business Intelligence, business decision

ABSTRAK

Artikel ini membahas Bisnis Intelligence dan peranannya untuk meningkatkan keunggulan kompetitif perusahaan melalui pendayagunaan berbagai data, informasi dan pengetahuan yang dimiliki oleh perusahaan sebagai bahan baku dalam proses pengambilan keputusan. Artikel ini juga menjelaskan elemen-elemen aplikasi Business Intelligence, Business Intelligence Environment, pengintegrasian BI ke dalam perusahaan dan tantangan yang dihadapi suatu organisasi dalam memberlakukan Business Intelligence.
\end{abstract}

Kata kunci: Business Intelligence, bisnis, keputusan

\section{PENDAHULUAN}

Analisis data telah menjadi kebutuhan utama dan vital dalam upaya meningkatkan daya saing bisnis sebuah organisasi atau perusahaan. Pengambilan keputusan bergaya entrepreneur yang cenderung mengandalkan intuisi menjadi kurang sesuai di tengah lingkungan persaingan bisnis yang semakin meningkat dan rumit. Naik turunnya penjualan sebuah produk tidak lagi hanya ditentukan oleh murah dan mahalnya harga jual atau baik buruknya kualitas produk. Ternyata, banyak faktor lain yang mempengaruhinya seperti kondisi demografi, geografi, penawaran pesaing, dan bahkan faktor emosional konsumen. Perusahaan memerlukan alat bantu yang mampu mengelola dan mengolah data yang dimilikinya menjadi informasi yang bernilai lebih dan tidak terpaku hanya pada angka-angka saja. Alat bantu tersebut harus mampu menterjemahkan berbagai hal implisit dan gejala penting dari sekumpulan data. Salah satu jawabannya adalah Business Intelligence, atau yang lebih sering disingkat dengan BI.

Business Intelligece (BI) merupakan aplikasi e-business yang berfungsi untuk mengubah data dalam perusahaan (data operasional, transaksional, dan lainnya) ke dalam bentuk pengetahuan. Aplikasi ini dapat melakukan analisis terhadap data dengan lebih efektif, misalnya untuk melakukan analisis dan membangun kesetiaan pelanggan untuk meningkatkan keuntungan perusahaan, menganalisis interaksi dengan pelanggan dan mengoptimalkan hubungan tersebut. Analisis terhadap transaksit-transaksi di masa lampau dan menggunakan pengetahuan tersebut untuk mendukung keputusan dan perencanaan operasi yang akan diambil perusahaan.

Ada beberapa permasalahan yang menuntut dan mendorong dikembangkannya aplikasi BI, yakni sebagai berikut,(1)bagaimana mengumpulkan danmengorganisasikan semua data internal perusahaan dalam suatu Integrated
Enterprise Information (data warehousing); (2) bagaimana memanfaatkan data perusahaan menjadi pengetahuan dalam perusahaan (data analytics); (3) bagaimana menyediakan pengetahuan yang berorientasikan kepada pelanggan (customer-centric), baik informasi yang berbeda-beda dan khusus untuk setiap pelanggan; (4) bagaimana analisis terhadap data perusahaan dapat memberikan dukungan terhadap pengambilan keputusan di pihak manajemen perusahaan yang sesuai dengan data tersebut; (5) bagaimana prosedur dan proses untuk mengintegrasikan BI ke dalam proses bisnis perusahaan; (6) faktor-faktor yang harus diperhatikan agar perusahaan dapat mengintegrasikan BI dengan mempertimbangkan resiko dan kesulitan yang mungkin dihadapi.

Berdasarkan kebutuhan perusahaan tersebut, maka dapat dilihat bahwa kebutuhan perusahaan untuk mengimplementasikan BI cukup besar. Namun, BI dengan data analysis tools-nya merupakan suatu aplikasi yang cukup mahal sehingga perlu diperhitungkan return on IT investment (ROI) dari implementasinya.

\section{Tinjauan Pustaka}

Business Intelligence (BI) adalah sebuah proses untuk meningkatkan keunggulan kompetitif perusahaan melalui pendayagunaan berbagai data, informasi, dan pengetahuan (knowledge) yang dimiliki oleh perusahaan sebagai bahan baku dalam proses pengambilan keputusan. Berbeda dengan sejumlah aplikasi lain dengan tujuan serupa yang lebih dahulu diperkenalkan sebelumnya, konsep BI menekankan pada penerapan 5 pendayagunaan informasi untuk keperluan spesifik bisnis, masing-masing adalah sebagai berikut.

Pertama, data sourcing. Berkaitan dengan kemampuan sistem untuk mengakses berbagai data dan informasi dari sejumlah sumber dengan format yang berbeda. Kedua, data analysis. Berkaitan dengan kemampuan sistem untuk 
membantu proses penciptaan pengetahuan (knowledge) melalui aktivitas pengkajian data dan informasi yang dimiliki oleh perusahaan. Ketiga, situation awareness. Berkaitan dengan kemampuan sistem untuk mencari dan menyediakan data dan informasi terkait dengan kebutuhan atau konteks bisnis pada saat tertentu, misalnya ketika perusahaan berhadapan dengan peristiwa darurat dan mendesak. Keempat, risk analysis. Berkaitan dengan kemampuan sistem untuk melakukan kalkulasi rasio yang akan dihadapi perusahaan terhadap berbagai kecenderungan atau kemungkinan yang dapat terjadi sehubungan dengan kondisi tertentu. Kelima, decission support. Berkaitan dengan kemampuan sistem untuk secara aktif membantu manajemen dalam memberikan pertimbangan keputusan-keputusan yang berkualitas berdasarkan sejumlah kalkulasi dan pengolahan terhadap data atau informasi internal maupun eksternal yang dimiliki.

Data mining adalah proses analisis terhadap data dengan penekanan menemukan informasi yang tersembunyi pada sejumlah besar data yang disimpan ketika menjalankan bisnis perusahaan.

Teknik data mining merupakan implementasi yang khusus dengan algoritma, yang digunakan pada operasi data mining. Ada 6 teknik umum data mining, antara lain sebagai berikut. Pertama, association. Digunakan untuk mengenali kelakuan dari kejadian-kejadian khusus atau proses. Link asosiasi muncul pada setiap kejadian. Kedua, sequence. Mirip dengan asosiasi, namun menghubungkan kejadiankejadian sepanjang waktu dan menentukan keterhubungan antar item untuk sepanjang waktu. Ketiga, classification. Melihat pada kelakuan dan atribut dari kelompok yang telah didefinisikan. Tool data mining dapat memberikan klasifikasi pada data baru dengan memanipulasi data yang ada, yang telah diklasifikasi dan dengan menggunakan hasilnya untuk memberikan sejumlah aturan. Aturan-aturan tersebut digunakan pada data-data baru untuk diklasifikasi. Teknik ini menggunakan supervised induction, yang memanfaatkan kumpulan pengujian dari record yang terklasifikasi untuk menentukan kelas-kelas tambahan. Keempat, cluster. Dapat digunakan untuk menganalisis pengelompokan berbeda terhadap data. Mirip dengan klasifikasi, namun pengelompokan belum didefinisikan sebelum dijalankannya tool data mining. Biasanya menggunakan metode neural network atau statistik. Clustering membagi item menjadi kelompok-kelompok berdasarkan yang ditemukan tool data mining. Kelima, regression (forecasting). Menggunakan nilai dari data yang diketahui untuk memperkirakan nilai di masa depan atau kejadian masa depan berdasarkan kecenderungan sejarah dan statistik. Keenam, time series (forecasting). Perbedaan dengan regresi adalah bahwa time series hanya memperkirakan data yang bergantung pada waktu.

Tool data mining memungkinkan dibangunnya model analisis yang merupakan tool yang digunakan selama operasi data mining. Hasil dari operasi data mining adalah tabeltabel dan file-file yang berisi data analisis yang dapat diakses dengan query dan tools reporting. Terdapat 4 operasi umum data mining, yakni sebagai berikut. Pertama, predictive and classification modelling. Digunakan untuk memperkirakan kejadian khusus. Diasumsikan bahwa seorang analis mempunyai pertanyaan khusus untuk ditanyakan. Model ini menyediakan jawaban dengan memberikan peringkat, yang menentukan kemiripan kelas-kelas tertentu. Kedua, link analysis. Mencari hubungan antara record-record pada basis data. Ketiga, database segmentation. Mengelompokkan record-record yang berhubungan ke dalam segmensegmen. Pengelompokan ini merupakan langkah pertama dari pemilihan data, sebelum operasi data mining lainnya dilakukan. Keempat, deviation detection. Mencari recordrecord yang dipandang tidak normal dan memberikan alasan untuk anomali tersebut.

\section{Metode Penelitian}

Tahapan pengembangan Business Intelligence adalah sebagai berikut. Pertama, justification. Langkah 1 adalah business case assessment. Kedua, planning. Langkah 2 adalah enterprise infrastructure; langkah 3 adalah project planning. Ketiga, business analysis. Langkah 4 adalah project requirements definition; langkah 5 adalah data analysis; langkah 6 adalah application prototyping; langkah 7 adalah meta data repository analysis. Keempat, design. Langkah 8 adalah database design; langkah 9 adalah extract/transform/ load (ETL) design; langkah 10 adalah meta data repository design. Kelima, construction. Langkah 11 adalah ETL development; langkah 12 adalah application development; langkah 13 adalah data mining; langkah 14 adalah meta data repository development. Keenam, deployment. Langkah 15 adalah implementation; langkah 16 adalah release evaluation.

Salah satu perangkat bantu yang digunakan untuk pengembangan Business Intelligence adalah SOL Server 2005, yang terdiri atas integration services, analysis services, dan reporting services.

\begin{tabular}{|l|l|l|}
\hline \multicolumn{1}{|l|}{ Integration Services } & \multicolumn{1}{|l|}{ Analysis Services } & Reporting Services \\
$\begin{array}{l}\text { Data acquisition } \\
\text { from source systems } \\
\text { and integration }\end{array}$ & $\begin{array}{l}\text { - Data enrichment with } \\
\text { business logic, } \\
\text { hierarchical views }\end{array}$ & $\begin{array}{l}\text { - Data presentation } \\
\text { and distribution } \\
\text { Data } \\
\text { masses }\end{array}$ \\
\hline $\begin{array}{l}\text { Data discovery via } \\
\text { data mining }\end{array}$ & \\
\hline
\end{tabular}

Gambar 1 Tiga Tahap Proses BI pada SQL Server 2005 Sumber: M.Choirul Amri (2006), Business Intelligence dengan SQLServer 2005 Membuat Data Menjadi Bermakna

Proses pengembangan BI dalam SQL Server 2005 terbagi dalam 3 tahap, yakni sebagai berikut. Pertama, integrasi. Tahap ini merupakan proses mengintegrasikan berbagai data dari berbagai sumber dan memasukkanya ke dalam data warehouse. Data dari sistem operasional divalidasi, diekstrak, diringkas, atau diberikan formula tertentu sesuai dengan hasil analisis bisnis. Proses ini juga dikenal sebagai extract, transform, loading (ETL) yang menggunakan SQL Server Intgration Services (SSIS). Sumber data tidak terbatas pada $S Q L$ Server saja, tetapi juga Oracle, DB2, flat file, XML, dan semua sumber data yang kompatibel dengan ODBC maupun OLEDB. Proses integrasi data tidak hanya sekedar melakukan import dari data source, tetapi termasuk juga proses validasi, agregasi, dan perhitungan menggunakan berbagai formula yang dikehendaki. Dengan proses ini, maka data yang dimasukkan ke data warehouse benar-benar siap untuk dianalisis.

Kedua, analisis. Dalam tahap ini, data di dalam data warehouse dianalisis menggunakan Analysis Services. Analysis Services merupakan alat bantu yang berisi berbagai metode data mining dan OLAP (Online Analytical Processing). Dalam proses data mining, SQL Server 2005 menyediakan 7 metode statistik yang dapat digunakan untuk menganalisis data, yaitu Microsoft Association Rules, Microsoft Clustering, Microsoft Decission Trees, Microsoft Linier Regression, Microsoft Logistic Regression, Microsoft Naive Bayes, dan Microsoft Neural Network.

Ketiga, penyajian laporan. Reporting services merupakan media utama dalam tahap penyajian laporan. Perangkat ini telah tersedia dalam SQL Server 2005 dan terintegrasi dengan Business Intelligence Development Studio. Di sisi server, terdapat report server yang melayani pengolahan dan penampilan laporan untuk end user. Reporting service berjalan di web browser sehingga sangat mudah untuk didistribusikan di intranet. Dengan demikian, tidak terdapat komponen yang harus diinstal di sisi klien. 


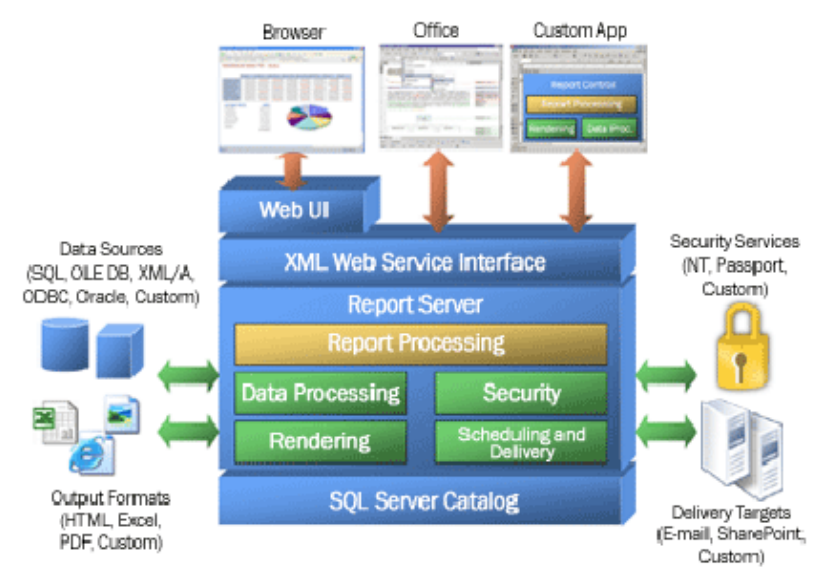

Gambar 2 Arsitektur Reporting Services

Sumber: M.Choirul Amri (2006), Business Intelligence dengan SQLServer 2005 Membuat Data Menjadi Bermakna

\section{PEMBAHASAN}

\section{Pentingnya Business Intelligence}

Seorang Chief Financial Officer (CFO) atau lebih dikenal sebagai direktur keuangan, sangat memerlukan status laporan keuangan secara korporasi ataupun laporan kinerja organisasi atau perusahaan yang dipimpinnya secara akurat dan menyeluruh. Bahkan sampai ke laporan balance scorecard untuk setiap divisi dalam organisasi tersebut.

Sebagai seorang kepala divisi penjualan, dia juga memerlukan informasi yang akurat mengenai kinerja bisnis sampai detail ke cabang organisasi, di mana pada setiap periode dilakukan penilaian dan perencanaan untuk periode berikutnya.

Seorang customer service manager juga dapat memperoleh data dan informasi analisis para pelanggannya sehingga dia dapat membuat keputusan terbaik berdasarkan informasi pelanggan tersebut dan memberikan pelayanan yang baik kepada pelanggannya.

Walaupun bekerja di belakang layar, peran $H R$ manager sangatlah penting sehingga dia dapat melakukan perhitungan dan analisis kinerja dari setiap individu yang ada dalam organisasi atau perusahaan, sampai dengan melakukan analisis produktivitas tiap karyawan serta dapat memikirkan perhitungan bonus yang diberikan bagi setiap individu yang berprestasi.

Bagi manajer pemasaran, dia dapat melakukan kampanye penjualan dengan segmentasi target yang jelas dan dapat diperhitungkan dalam menyumbang penerimaan bagi organisasinya, dan masih banyak lagi evaluasi kinerja manajemen dari setiap divisi yang dilakukan pada suatu organisasi atau perusahaan.

Jelas sekali bahwa Business Intelligence diperlukan di setiap lini dalam suatu organisasi yang harusnya sudah tertanam dalam setiap langkah bisnis, guna mencapai tujuan perusahaan yang lebih baik, lebih efisien dan efektif sehingga mendapat profit yang optimal.

Adapun tantangan yang dihadapi suatu organisasi dalam memberlakukan Business Intelligence antara lain (1) informasi biasanya sangat didominasi dari atas, atau dari analis, baik dari luar maupun dalam organisasi. Informasi dari barisan paling depan frontliner ataupun bagian tengah kurang diperhatikan; (2) informasi sangat terpisah-pisah dan sangat beragam dalam divisi dari organisasi, kadang sangat berbeda tingkat keakuratan dan kebenarannya; (3) kurang konsistensinya standar penerapan Business Intelligence dalam setiap divisi dalam organisasi; (4) tidak adanya satu kesatuan single view of information.
Business Intelligence (BI) merupakan perkembangan dari aplikasi Knowlegde Management (KM), dengan menambahkan proses data analytics, yaitu dengan memanfaatkan data yang ada untuk menghasilkan suatu informasi baru yang bermanfaat. Aplikasi BI memberikan informasi yang personal, yaitu dengan melakukan proses pengumpulan, pengaturan, dan penyebaran informasi secara personal sesuai dengan kebutuhan tiap divisi dalam suatu organisasi atau perusahaan. Aplikasi BI menggunakan teknologi e-commerce untuk menghubungkan data warehousing dengan perangkat client (seperti mobile device). Agar BI dapat berfungsi dengan baik, maka diperlukan kerangka yang terintegrasi dengan beberapa kelas dari aplikasi Knowlegde Management (KM) sehingga perlu diadaptasi beberapa elemen dari Knowlegde Management, di antaranya adalah sebagai berikut.

Pertama, pengorganisasian dan pengumpulan data atau content. Data tentang pelanggan, mitra, dan pemasok disimpan pada beberapa tempat di dalam perusahaan. Dibutuhkan suatu pandangan yang terintegrasi untuk memungkinkan perusahaan mengetahui dan merespon seakuratmungkin terhadap pelanggannya. Berikut inibeberapa faktor yang mempengaruhi keberhasilan integrasi data, yaitu (1) scalability, yaitu ukuran basis data (storage's space) yang disediakan perusahaan harus mampu menampung informasi customer-centric yang dapat mencapai beberapa gigabyte per hari; (2) flexibility, yaitu kemampuan untuk mengakomodasi bermacam-macam data model dan arsitektur basis data dan memungkinkan integrasi dengan sistem informasi back-end lainnya; (3) performance, yaitu kemampuan untuk menangani query-query dengan cepat dan akurat.

Kedua, analisis dan segmentasi. Tools untuk data mining terdapat pada aplikasi ini, tujuannya adalah untuk meningkatkan nilai data dan informasi, mempertahankan pelanggan dan menemukan jalur pendapatan perusahaan yang baru. Proses mining ini dimulai dengan membangun gambaran lebih jelas tentang kelakuan pelanggan. Tanpa tool analisis tersebut, maka usaha menyimpan informasi customer-centric yang sangat besar jumlahnya tersebut menjadi sia-sia. Namun, proses analisis tersebut tidak sederhana meskipun data telah tersentralisasi, merupakan usaha yang berat untuk mengubah informasi tersebut menjadi pengetahuan yang menghasilkan keuntungan dan dapat menjalin hubungan jangka panjang dengan pelanggan. Elemen teknis yang dimanfaatkan untuk proses ini adalah data mining dengan tools OLAP (Online Analyticals Processing).

Ketiga, personalisasi yang real-time. Kemampuan personalisasi dari perusahaan memungkinkan perusahaan memahami dan merespon setiap kebutuhan, kelakuan, dan perhatian pelanggan untuk meyakinkan bahwa pelanggan tersebut mendapatkan kebutuhannya. Aplikasi pendukung personalisasi memungkinkan pembuatan produk atau layanan yang customized dengan meminimalkan biaya marginal dari personalisasi tersebut. Beberapa tahapan (siklus) personalisasi, yakni (1) profiling, menunjukkan produk yang ditawarkan dan menanyakan kebutuhan pelanggan; (2) matching, memberikan kebutuhan pelanggan dan menyesuaikan data dengan kebutuhan pelanggan; (3) transacting, kebebasan untuk self-service dan memudahkan transaksi; (4) listen, memfasilitasi tanggapan pelanggan dan mengukur keefektifannya.

Keempat, penyebaran, pengambilan dan interaksi terhadap informasi. Infrastruktur untuk proses interaksi dan pengiriman atau penerimaan informasi dengan pelanggan adalah menggunakan media yang dipilih oleh pelanggan tersebut. Meskipun penggunaan WWW sudah umum, namun strategi KM yang baik adalah dengan menjangkau semua media yang digunakan pelanggannya, seperti telephone, WAP, TV ataupun $e$-mail.

Kelima, pemantauan dan pengukuran kinerja sistem. Aplikasi pemantauan kinerja sistem ini menyediakan informasi yang dibutuhkan manajer untuk meningkatkan operasi dan strategi. Dengan menggunakan Key Performace 
Indicator (KPI) yang dihubungkan dengan balaced scorecard, perusahaan dapat secara bekelanjutan memantau kinerja proses terhadap target dari strateginya. Sistem pemantauan yang efektif adalah yang mampu membuat strategi menjadi tindakan.

Business Intelligence (BI) merupakan suatu proses yang mengumpulkan dan mengubah sejumlah besar data yang ada dalam suatu organisasi menjadi informasi yang berguna. Implementasi BI dalam suatu organisasi memerlukan proses yang panjang, banyak analisa dan investasi uang yang cukup besar. BI environment melibatkan business model, data model, data source, ETL, alat (tools) untuk mengorganisasikan, dan mentrasformasikan data menjadi informasi yang berguna, target data warehouse, data mart, OLAP analysis, dan reporting tools.

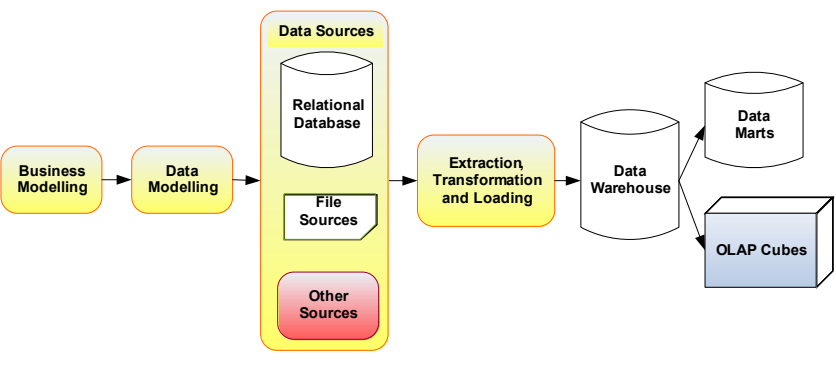

Gambar 3 Business Intelligence Environment Sumber: www.learnbi.com (2007)

Business Modelling menggambarkan gambaran keseluruhan proses bisnis dan masalah-masalah yang harus diselesikandandiatasinya, danjugamenggambarkanbagaimana informasi mengalir pada proses-proses bisnis dari sumber informasi ke tujuan. Dalam membuat business modelling digunakan business model dan diagram yang memberikan informasi secara grafis bagi anggota suatu organisasi atau perusahaan memahami dan mengkomunikasikan business rule dan proses-proses bisnisnya. Business process modelling, process flow modelling dan data flow modelling adalah subbagian dari suatu business modelling. Business modelling strategy dan business model suatu organisasi atau perusahaan berbeda satu dengan yang lainnya, hal ini tergantung pada kebutuhan dan tujaun perusahaan atau organisasi tersebut.

Pertama, business process modelling. Business process modelling berisi sekelompok aktifitas atau proses bisnis yang saling terkait, digambarkan dalam bentuk diagram atau grafik beserta teks. Busienss process modelling biasa juga disebut dengan business process model. Kedua, process flow modelling. Process flow modelling digunakan untuk menggambarkan secara grafis proses-proses bisnis yang terjadi pada suatu organisasi atau perusahaan serta hubungan antar masing-masing proses tersebut. Ketiga, data flow modelling. Data flow modelling (DFD) menggambarkan aliran data antar proses-proses bisnis dari suatu organisasi atau perusahaan beserta aliran dokumen-dokumen pendukungnya.

Data modelling menggambarkan secara nyata struktur data atau entity-entity beserta relasi-relasinya, disajikan dalam bentuk data model. Dapat dikatakan data model merupakan gambaran visual dari suatu database. Data modelling terdiri atas conceptual data modelling, logical data modelling, physical data modelling, enterprise data modelling, relational data modeling, dan dimensional data modelling.

Extraction, Transformation and Loading (ETL) merupakan sekumpulan proses yang terkait dengan proses menarik data dari sumber data, transformasi data dan meletakan data pada data warehouse. Sebelum data diletakan pada data warehouse, data diubah ke bentuk yang dibutuhkan data warehouse. Untuk itu dilakukan proses data cleansing, data profiling, data type conversion, validasi referential integrity, performing aggregation, de-normalization, dan normalization.
Data warehouse merupakan tempat penyimpanan untuk ringkasan dari data historis yang seringkali diambil dari database departemen atau perusahaan terpisah. Data warehouse mengumpulkan semua data perusahaan dalam satu tempat untuk memberikan pandangan yang lebih baik dari proses bisnis dan dapat meningkatkan kinerja organisasi. Data warehouse mendukung proses pembuatan keputusan manajemen, proses ini subject-oriented, terintegrasi, waktu yang bervariasi dan permanen (karakteristik data warehouse). Data warehouse berfokus pada konsep bisnis daripada proses bisnis dan menampung semua informasi penjualan yang relevan yang dikumpulkan dari beberapa sistem pemroses.

Data mart merupakn sub-set dari data warehouse, dibuat untuk kebutuhan analisa khusus terhadap proses bisnis tertentu pada suatu departemen di suatu organisasi atau perusahaan. Data mart menyimpan data tertentu dari suatu subjek area tertentu, misalnya data pada bagian sales atau purcahsing. Data mart dapat diturunkan dari data warehouse atau dibuat untuk tujuan business intelligence tersendiri. Seperti halnya data warehouse, data mart dibuat dalam bentuk dimensional data model.

\section{Online Analytical Processing (OLAP)}

Online Analytical Processing (OLAP) merupakan kunci dari BI, digunakan untuk meningkatkan analisis bisnis, merupakan perhitungan Decision Support System (DSS) dan Expert Infotmation System (EIS) yang dilakukan oleh end-user pada sistem online. OLAP digunakan pada banyak aplikasi, mulai dari pelaporan (reporting) perusahaan sampai DSS. Beberapa aktivitas yang dilakukan OLAP antara lain generate query, meminta laporan ad hoc, mendukung analisis statistik, analisis interaktif, dan membangun aplikasi multimedia. Untuk memfasilitasi OLAP ini diperlukan data warehouse dengan sekumpulan tool yang memiliki kemampuan multidimensi. Tool ini dapat berupa tool query, spreadsheet, tool data mining, dan data visualisasi.

Intelligent Business adalah tentang bagaimana memindahkan sistem BI ke inti dari perusahaan dan menghubungkannya sampai ke sistem operasional sehingga dapat menurunkan kemungkinan untuk melakukan mekanisme standar industri (penurunan biaya operasional). Terdapat beberapa cara untuk mengintegrasikan BI ke dalam perusahaan, di antaranya adalah mengintegrasikan aplikasi analisis dengan aplikasi operasional menggunakan portal perusahaan untuk dapat diakses dan dimanfaatkan oleh pengguna baik internal maupun eksternal; menyatukan analisis pada aplikasi operasional selama pengembangan aplikasi; pengenalan web service untuk secara dinamis mengintegrasikan proses analisis dengan internal dan mitra aplikasi operasional untuk mendukung kolaborasi penjualan; dan membangun proses on-demand yang event-driven untuk peringatan ke pengguna, rekomendasi real-time dan aksi yang terotomatisasi. Pendekatan ini termasuk Business Activity Monitoring (BAM).

Aplikasi BI merupakan proyek rekayasa sistem dan hal tersebut mencakup 6 proses pengerjaan yang utama, antara lain sebagai berikut. Pertama, justification, yaitu penaksiran terhadap permasalahan dan kemungkinan bisnis yang meningkatkan proyek rekayasa sistem. Langkah 1 adalah business case assessment. Kedua, planning, yaitu pengembangan perencanaan strategis dan taktis yang menyusun bagaimana pencapaian proyek rekayasa sistem. Langkah 2 adalah enterprise infrastructure; langkah 3 adalah project planning. Ketiga, business analysis, yaitu analisis rinci dari permasalahan dan kesempatan bisnis yang menyediakan pemahaman baku atas kebutuhan solusi bisnis. Langkah 4 adalah project requirements definition; langkah 5 adalah data analysis; langkah 6 adalah application prototyping; langkah 7 adalah meta data repository analysis. Keempat, design, yaitu penyusunan produk yang menyelesaikan permasalahan bisnis dan memberikan peluang untuk kesempatan bisnis. Langkah 8 adalah database design; langkah 9 adalah Extract/Transform/ 
Load (ETL) Design; langkah 10 adalah meta data repository design. Kelima, construction, yaitu pembangunan produk yang disusun yang diharapkan dapat memberikan return on development investment dalam kerangka yang jelas. Langkah 11 adalah ETL development; langkah 12 adalah application development; langkah 13 adalah data mining; langkah 14 adalah meta data repository development. Keenam, deployment, yaitu barang jadi diimplementasikan (dijual) dan diukur efektifitasnya yang akan menentukan apakah solusi ditemukan, melebihi atau gagal terhadap return on investment (ROI). Langkah 15 adalah implementation; langkah 16 adalah release evaluation. Urutan proses pengerjaan dan langkahlangkah pembangunan aplikasi BI terdapat pada Gambar 4 di bawah ini.

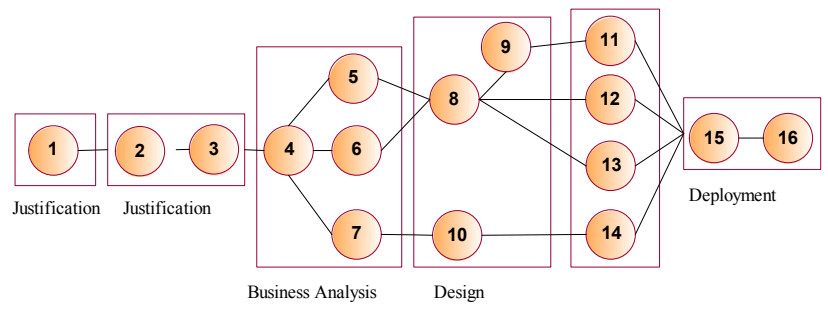

Gambar 4 Langkah-langkah pembangunan BI

Sumber: Noverino Rifai dan Kharizt Attria Gupta (2004), Business Intelligence"

Kesulitan utama dari pengimplementasian BI adalah pengintegrasiannya dengan perusahaan, terutama proses bisnisnya. Berikut ini adalah masalah-masalah yang mungkin dihadapi dan dapat menyebabkan kegagalan mengintegrasikan BI, yakni (1) kebingungan terhadap arti dari data, misalnya karena tidak ada pemahaman yang umum terhadap data; (2) perubahan tujuan bisnis tahunan meskipun tujuan yang ditetapkan pada tahun sebelumya belum dicapai, aplikasi Business Intelligence tidak mampu mengikuti perubahan tujuan perusahaan yang tidak teratur tersebut; (3) ketidakmampuan menentukan skala bisnis karena kurangnya integrasi proses bisnis dan otomatisasinya. Fixed cost selalu bertambah seiring dengan pertambahan skala bisnis dan variable cost yang sedikit. Akibatnya, biaya operasional terlalu tinggi karena terlalu banyak kegiatan manual dan kesalahan proses karena sistem yang tidak terintegrasi; (4) pengguna suatu sistem tidak diberitahu atas kejadian yang terjadi pada sistem lainnya; (5) tidak bereaksi secara langsung terhadap kejadian-kejadian pada proses bisnis operasi, misalnya perubahan, pembatalan pesanan, pembayaran telat, persediaan barang yang habis, akibatnya mengurangi kesempatan bisnis dan ketidakmampuan merespon terhadap permasalahan ketika muncul; (6) mencocokkan ulang data ke dalam sistem yang berbeda; (7) redundansi data yang besar, terpotong-potong, dan tidak konsisten pada sistem yang berbeda-beda; (8) konflik pada perlakuan pelanggan oleh customer service, pemasaran dan penjualan pada chanelchanel yang berbeda.

\section{Alasan menggunakan Business Intelligence}

Alasan menggunakan Business Intelligence adalah sebagai berikut. Pertama, membuat data lebih bermakna. Untuk mengambil data yang tersimpan di sistem TI suatu perusahaan, banyak perusahaan berpaling ke piranti lunak BI. Banyak perusahaan yang berinvestasi di ERP atau CRM, namun tidak mendapatkan hasil yang diharapkan. Biasanya, sistem ERP dapat mengumpulkan data, tapi laporan yang dihasilkan kadang tidak sepadan. Piranti lunak BI memungkinkan mengambil data yang tersimpan di sistem ERP, spreadsheet Excel dan database Oracle dan Microsoft Access, dan menyimpannya di RAM server sehingga untuk mencetak laporan bulanan cukup dengan mengakses data dari intranet perusahaan kapan saja mereka inginkan sehingga para sales people dan eksekutif dapat mempelajari data yang terbarui setiap hari. Kedua, membantu pengambil keputusan. Selain mudah mengakses data, piranti lunak BI sangat mempengaruhi suatu proses negosiasi, yakni dengan memudahkan kuantifikasi nilai hubungan dengan pemasok maupun pelanggan utama. Ketiga, melacak produk dan penjualan terpanas. Di beberapa perusahaan, BI juga dimanfaatkan untuk mengelola inventori. Perusahaan ritel menggunakan piranti BI untuk mencari produk-produk yang sudah tersimpan di salah satu gudangnya lebih dari hari yang ditentukan. Perusahaan mengumpankan informasi tersebut ke dalam piranti lunak supply chain kemudian menarik produk ini dari pusat distribusi dan menjualnya ke toko-toko dengan harga lebih rendah. Para peritel juga menggunakan piranti BI untuk membantu mencari tahu produk mana yang sukses, mana yang tak berhasil tak lama setelah produk tersebut memasuki toko. Status pelanggan pun tak luput dari pantauan piranti BI. Piranti BI dapat digunakan untuk mengetahui berapa jumlah kehilangan pelanggan dan berapa pelanggan baru yang berhasil didapatkan bulan ini. Informasi ini tidak sekedar ditampilkan secara umum, namun juga dapat dirinci berdasarkan wilayah teritorinya.

Dalam kerangka arsitektur sistem informasi, BI dapat merupakan sebuah paket software atau modul berdiri sendiri, maupun merupakan bagian (embedded) dari sebuah paket aplikasi. Kebanyakan software yang terkait dengan pengambilan keputusan yang dikembangkan setelah tahun 1993 telah memiliki fasilitas BI di dalamnya. Sementara itu, beberapa software yang dikembangkan sebelumnya memerlukan tambahan modul khusus, yang berfungsi sebagai BI Tools, yang bertugas untuk mengintegrasikan dan memadukan berbagai data dan informasi yang tersebar pada sejumlah aplikasi berbeda di dalam sebuah perusahaan Gambar 5.

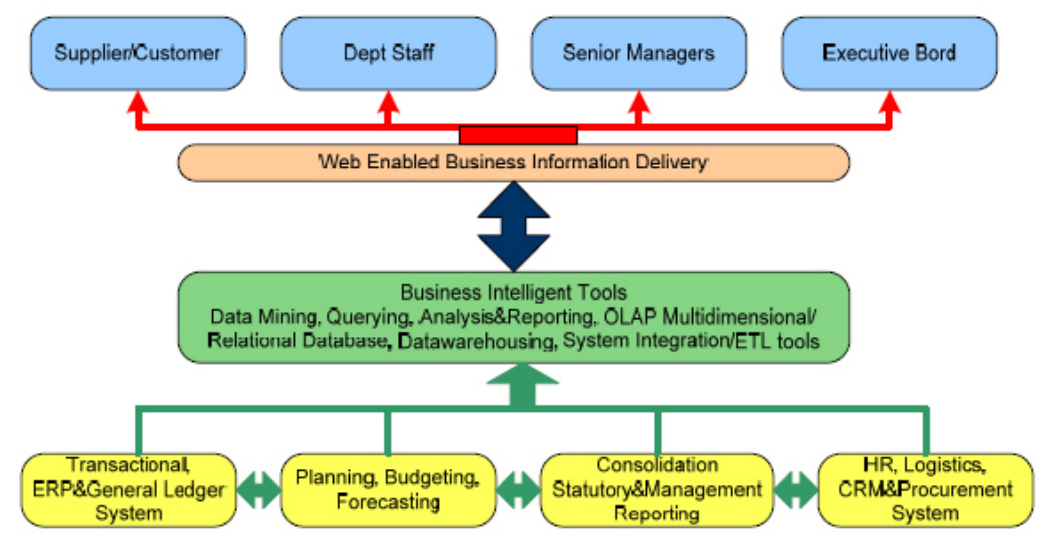

Gambar 5 Business Intelligence dalam Kerangka Arsitektur Sistem Informasi

Sumber: eBizzAsia. 2004 
Business Intelligence memungkinkan pengambil keputusan berbuat berdasarkan intelligence dengan menggunakan strategi BI. Jika pengetahuan atau informasi tidak digunakan dengan tepat dan dengan arah yang tepat, maka analisis pada BI sulit untuk dilakukan. Business intelligence berisi strategi-strategi untuk meningkatkan proses bisnis secara efisien dan mengurangi biaya-biaya operasi proses-proses bisnis tersebut. Implementasi sistem BI pada suatu perusahaan atau organisasi membutuhkan investasi biaya besar yang dikeluarkan untuk membangun dan implementasi sistem BI serta aplikasi yang terkait dengannya. Pimpinan tertinggi suatu organisasi atau perusahaan perlu membuat Return on Investment (ROI) model untuk menganalisis biaya yang dibutuhkan bagi implementasi dan pemeliharaan BI model serta menentukan metode-metode untuk mengembalikan investasi biaya yang sudah dikeluarkan segera. Tindakan-tindakan bisnis yang tepat perlu dilakukan berdasarkan strategi dari intelligence model. Kadang model BI dan asumsi yang salah dalam membuat model BI dapat mengurangi manfaat yang seharusnya diperoleh dari digunakannya sistem BI itu sendiri. Jika model BI sudah dirancang dengan tepat dan sesuai dengan kebutuhan dan tujuan organisasi atau perusahaan, maka keuntungan akan diperoleh oleh perusahaan sesuai dengan biaya yang sudah dikeluarkan.

\section{PENUTUP}

Simpulan mengenai Business Intelligence (BI) dari pembahasan, yaitu (1) analisis data telah menjadi kebutuhan utama dan vital dalam upaya meningkatkan daya saing bisnis sebuah organisasi atau perusahaan; (2) pengambilan keputusan bergaya entrepreneur yang cenderung mengandalkan intuisi menjadi kurang sesuai di tengah lingkungan persaingan bisnis yang semakin meningkat dan rumit; (3) BI merupakan aplikasi e-business yang berfungsi untuk mengubah data dalam perusahaan (data operasional, transaksional, dan lainnya) ke dalam bentuk pengetahuan; (4) BI menekankan pada penerapan 5 pendayagunaan informasi untuk keperluan spesifik bisnis, masing-masing adalah data sourcing, data analysis, situation awareness, risk analysis, dan decission support; (5) BI merupakan suatu proses yang mengumpulkan dan mengubah sejumlah besar data yang ada dalam suatu organisasi menjadi informasi yang berguna. BI environment melibatkan business model, data model, data source, ETL, alat (tools) untuk mengorganisasikan dan mentrasformasikan data menjadi informasi yang berguna, target data warehouse, data mart, OLAP analysis dan reporting tools; (6) proses analisis berfungsi mengubah data mentah atau data rangkuman pada data warehouse menjadi suatu informasi bagi perusahaan; (7) informasi yang dihasilkan analisis dapat dimanfaatkan oleh sistem pendukung keputusan yang menjadi sumber dalam mengambil keputusan di pihak manajemen Untuk mengintegrasikan BI ke dalam proses bisnis perusahaan, perlu dilakukan beberapa proses siklus pengembangan sistem (JustificationPlanning Business Analysis Design Construction Deployment); (8) agar perusahaan dapat mengintegrasikan BI, perlu diperhatikan beberapa faktor, antara lain pemahaman terhadap tujuan perusahaan, pemahaman terhadap pentingnya aplikasi BI ini terhadap pengguna, dan memposisikan aplikasi BI ini dengan sistem lain di dalam perusahaan; (9) implementasi sistem BI pada suatu perusahaan atau organisasi membutuhkan investasi biaya besar yang dikeluarkan untuk membangun dan implementasi sistem BI serta aplikasi yang terkait dengannya. Pimpinan tertinggi suatu organisasi atau perusahaan perlu membuat Return on Investment (ROI) model untuk menganalisa biaya yang dibutuhkan bagi implementasi dan pemeliharaan BI model serta menetukan metode-metode untuk mengembalikan investasi biaya yang sudah dikeluarkan segera.

\section{DAFTAR PUSTAKA}

Barberg, B. (2007). Building roads: getting to a shared understanding of BI costs and benefits. Diakses 9 Juli 2007 dari http://www. bussinessintelligence.com.

Choirul A.M. (2006). Business Intelligence dengan SQL Server 2005 membuat data menjadi bermakna. Diakses 22 Juli 2007 dari http://www. ilmukomputer.com.

eBizzAsia. (2004). Solution and strategies IT and communications: Business Intelligence bukan sembarang intel korporat. eBizzAsia, 1, 05 (Maret), 15.

Eko I.R. (2003). Question and answer: Business Intelligence (BI). eBizzAsia, 1, 05 (Maret), 82-83.

Rifai, N., dan Gupta, K.A. (2004). Business Intelligence. Fakultas Teknologi Industri, Institut Teknologi Bandung.

Snow, C. (2007). Supply chain BI improves customer satisfaction. Diakses 9 Juli 2007 dari http://www. bussinessintelligence. com.

Zainudin, A., dan Sugianto, B. (2005). Aplikasi Business Intelligence untuk pemasaran. Diakses 5 Juli 2007 dari http://www. swa. co.id. 